\title{
Erratum to: Text mining facilitates database curation - extraction of mutation-disease associations from Bio-medical literature
}

Komandur Elayavilli Ravikumar, Kavishwar B. Wagholikar, Dingcheng Li, Jean-Pierre Kocher and Hongfang Liu*

Unfortunately, the original version of this article [1] contained an error. The family name of the last author ("Liu") was captured as a given name, and "PhD" was captured as a family name. The correct first name is "Hongfang" and the correct family name is "Liu". This is included correctly in the author list above.

Received: 1 March 2016 Accepted: 1 March 2016

Published online: 13 April 2016

\section{Reference}

1. Ravikumar KE, Wagholikar KB, Li D, Kocher J-P, Liu H. Text mining facilitates database curation - extraction of mutation-disease associations from Bio-medical literature. BMC Bioinformatics. 2015;16:185.

Submit your next manuscript to BioMed Central and we will help you at every step:

- We accept pre-submission inquiries

- Our selector tool helps you to find the most relevant journal

- We provide round the clock customer support

- Convenient online submission

- Thorough peer review

- Inclusion in PubMed and all major indexing services

- Maximum visibility for your research

Submit your manuscript at www.biomedcentral.com/submit
Biomed Central 